\title{
TINGKAT PENGETAHUAN TENTANG PENANGANAN OBAT DALAM SWAMEDIKASI DAN PENGARUHNYA TERHADAP KEBIASAAN MENGGUNAKAN OBAT PADA RESPONDEN DI APOTEK GUNUNG SARI
}

\section{(KNOWLEDGE LEVEL ON MEDICINE HANDLING IN SELF MEDICATION AND ITS EFFECT ON RESPONDENCES HABIT OF MEDICINE USAGE IN GUNUNG SARI PHARMACY)}

\author{
NI PUTU UDAYANA ANTARI ${ }^{1}$, AGUS SUNADI PUTRA $^{1}$ \\ ${ }^{1}$ Akademi Farmasi Saraswati Denpasar, Jalan Kamboja No.11A, Denpasar, Bali
}

\begin{abstract}
Abstrak: The International Pharmaceutical Federation (FIP) mendefinisikan swamedikasi atau selfmedication sebagai penggunaan obat-obatan tanpa resep oleh seorang individu atas inisiatifnya sendiri (FIP, 1999). Swamedikasi hendaknya dilaksanakan berdasarkan tingkat pengetahuan yang cukup untuk menghindari penyalahgunaan atau penggunasalahan obat, serta kegagalan terapi akibat penanganan obat yang tidak sesuai. Menurut WHO (2012) pengetahuan yang cukup akan mempengaruhi seseorang untuk berperilaku atau melakukan sesuatu. Dengan demikian penelitian ini bertujuan untuk mengetahui tingkat pengetahuan responden tentang penanganan obat dalam swamedikasi, kebiasaan responden dalam menggunakan obat, dan pengaruh tingkat pengetahuan tentang penanganan obat dalam swamedikasi terhadap kebiasaan menggunakan obat di Apotek Gunung Sari. Penelitian dilakukan dengan menyebarkan kuesioner yang terdiri dari kuesioner untuk menilai kebiasaan responden dalam menggunakan obat dan kuesioner untuk menilai tingkat pengetahuan responden tentang penanganan obat dalam swamedikasi kepada 50 responden. Hasil penelitian menunjukkan bahwa tingkat pengetahuan responden di Apotek Gunung Sari tentang penanganan obat dalam swamedikasi termasuk dalam kategori cukup dengan persentase rata-rata 74,12\%, kebiasaan responden dalam menggunakan obat termasuk dalam kategori positif dengan persentase rata-rata $75,17 \%$ dan tidak ada pengaruh yang bermakna antara tingkat pengetahuan tentang penanganan obat dalam swamedikasi terhadap kebiasan responden dalam menggunakan obat.
\end{abstract}

Kata kunci: kebiasaan, penanganan obat, pengetahuan, penggunaan obat, swamedikasi.

\begin{abstract}
The International Pharmaceutical Federation (FIP) defines swamedikasi or self-medication as the use of medications without a prescription by an individual on his own initiative (FIP, 1999). Self-medication should be implemented based on the level of knowledge to avoid abuse or misuse of drugs, as well as treatment failure due to non appropriate drug treatment. According to WHO (2012) sufficient knowledge will influence someone to behave or do something. Thus, this study aims to determine the level of knowledge about handling drug in self-medication, the respondens habit on using drugs, and the correlation between level of knowledge about handling drugs in self-medication and the habit of using drugs in the pharmacy Gunung Sari. The study was conducted by distributing a questionnaire consisting of a questionnaire to assess the respondents habit of using drugs and a questionnaire to assess the level of knowledge about the handling of drugs in swamedikasi to 50 respondents. The results showed that the level of respondents knowledge in the pharmacy Gunung Sari on handling drug in swamedikasi is moderate with an average percentage of $74.12 \%$, the habit of respondens in using the drugs come under positive category with an average percentage of $75.17 \%$ and no significant correlation between the level of knowledge about handling drugs in swamedikasi and the habits of respondents in using drugs
\end{abstract}

Keywords: drug treatment, drug use, habits, knowledge, self-medication.

\section{PENDAHULUAN}

Berbagai data menunjukan bahwa swamedikasi menjadi alternatif yang paling banyak dipilih oleh masyarakat untuk meredakan atau menyembuhkan keluhan kesehatan ringan.
Berdasarkan hasil Susenas tahun 2011, BPS mencatat bahwa terdapat $66,82 \%$ orang sakit di Indonesia yang melakukan swamedikasi. Angka ini relatif lebih tinggi dibandingkan persentase penduduk yang berobat jalan ke dokter $(45,8 \%)$ (BPS, 2011).

•email korespondensi: putuudayana87@gmail.com 
The International Pharmaceutical Federation (1999) mendefinisikan swamedikasi atau self-medication sebagai penggunaan obatobatan tanpa resep oleh seorang individu atas inisiatifnya sendiri. Swamedikasi hendaknya dilaksanakan berdasarkan tingkat pengetahuan yang cukup untuk menghindari penyalahgunaan atau peggunasalahan obat serta kegagalan terapi akibat penanganan obat yang tidak benar.

Pengetahuan (knowledge) merupakan hasil dari tahu dan ini terjadi setelah orang melakukan pengindraan terhadap suatu objek tertentu. Penginderaan terjadi melalui panca indra manusia, yakni: indra pengelihatan, pendengaran, penciuman, rasa dan raba. Sebagian besar pengetahuan manusia diperoleh melalui mata dan telinga (Notoatmodjo, 2003). Menurut WHO (2012) Pengetahuan yang cukup juga akan mempengaruhi seseorang untuk berperilaku atau melakukan sesuatu karena seseorang mencari tahu informasi yang ada disekitarnya. Pengetahuan adalah salah satu faktor predisposisi yang dapat mempengaruhi terbentuknya perilaku seseorang (Pratiwi dkk, 2014).

Perilaku adalah tindakan atau aktivitas dari manusia itu sendiri yang mempunyai bentangan yang sangat luas antara lain: berjalan, berbicara, menangis, tertawa, bekerja, kuliah, menulis dan sebagainya. Dari uraian ini dapat disimpulkan bahwa yang dimaksud perilaku manusia adalah semua kegiatan atau aktivitas manusia, baik yang diamati langsung, maupun yang tidak dapat diamati oleh pihak luar. Prilaku merupakan respons atau reaksi seseorang terhadap rangsangan dari luar (Notoatmodjo, 2010). Menurut Kamus Besar Bahasa Indonesia kebiasaan adalah sesuatu yang biasa dikerjakan atau antar pola untuk melakukan tanggapan terhadap situasi tertentu yang dipelajari oleh seorang individu dan yang dilakukannya secara berulang untuk hal yang sama.

Penelitian ini bertujuan untuk mengetahui tingkat pengetahuan responden tentang penanganan obat dalam swamedikasi, kebiasaan responden dalam menggunakan obat, dan pengaruh tingkat pengetahuan tentang penanganan obat dalam swamedikasi terhadap kebiasaan responden dalam menggunakan obat di Apotek Gunung Sari. Adapun rumusan masalah dalam penelitian ini adalah sebagai berikut:

1. Bagaimanakah tingkat pengetahuan responden di Apotek Gunung Sari tentang penanganan obat dalam swamedikasi ?

2. Adakah pengaruh tingkat pengetahuan tentang penanganan obat dalam swamedikasi terhadap kebiasan responden dalam menggunakan obat?

\section{METODE PENELITIAN}

Penelitian dilakukan dengan menyebarkan kuesioner yang terdiri atas kuesioner untuk menilai kebiasaan responden dalam menggunakan obat dan kuesioner untuk menilai tingkat pengetahuan responden tentang penanganan obat dalam swamedikasi. Kuesioner yang digunakan diuji validitas dan reliabilitasnya kepada 30 responden serta dikonsultasikan kepada 3 ahli tata bahasa Indonesia dan lima orang Apoteker.

Uji validitas yang digunakan adalah tekhnik korelasi Product Moment Pearson. Pengukuran reliabilitas dilakukan dengan metode one shot (sekali ukur). Kriteria pengujian adalah jika nilai Cronbach Alpha hitung $>60$, maka instrumen yang diuji tersebut dapat dinyatakan telah reliabel. Pertanyaan - pertanyaan yang tidak memenuhi syarat uji validitas dan reliabilitas digugurkan, sisa pertanyaan disusun kembali untuk dijadikan alat penelitian

Kuesioner yang telah valid ( $\mathrm{r}$ hitung $>\mathrm{r}$ tabel menurut korelasi Product Moment Pearson) dan reliabel (Cronbach Alpha hitung > 60) nilai kemudian disebarkan kepada 50 responden yang menjadi sampel penelitian. Jumlah sampel penelitian diperoleh melalui perhitungan rumus menurut Lemenshow dkk. (1997) sebagai berikut:

$$
n=\frac{\mathrm{Z}_{1}{ }^{2}-\frac{\alpha}{2} \cdot \mathrm{p}(1-\mathrm{p})}{d^{2}}
$$

Keterangan:

$$
\begin{aligned}
& \text { n } \propto \text { : jumlah sampel minimal } \\
& \mathrm{Z}_{1}{ }^{2}-\frac{\alpha}{2} \text { : derajad kepercayaan } 95 \%(1,96) \\
& \mathrm{p} \quad \text { : proporsi populasi } 50 \%(0,5) \\
& \text { d : tingkat presisi/penyimpangan } \\
& \text { terhadap populasi } 14 \%(0,14)
\end{aligned}
$$

Pengambilan sampel dilakukan dengan sistem purposive sampling dengan kriteria inklusi dan eksklusi sebagai berikut:

Kriteria Inklusi:

1. Pasien yang membeli obat tanpa resep di Apotek Gunung Sari.

2. Pendidikan minimal SMA/sederajat atau sedang mengenyam pendidikan di tingkat SMA/sederajat.

3. Minimal berusia 16 tahun. 
Kriteria Eksklusi:

1. Masyarakat yang tidak kooperatif.

2. Terdapat keadaan yang tidak memungkinkan untuk dilakukan penelitian.

Penilaian untuk kuesioner tingkat pengetahuan tentang penanganan obat dalam swamedikasi dilakukan dengan memberi point 1 jika responden menjawab dengan benar dan poin " 0 " jika responden tidak menjawab pertanyaan dengan benar. Tingkat pengetahuan responden diklasifikasikan berdasarkan tabel 1 .

Tabel 1. Klasifikasi Tingkat Pengetahuan Responden

\begin{tabular}{|c|c|}
\multicolumn{2}{|c|}{ Responden } \\
\hline Klasifikasi & Nilai Responden \\
\hline Baik & $76-100 \%$ \\
\hline Cukup & $56-75 \%$ \\
\hline Kurang & $\leq 55 \%$ \\
\hline
\end{tabular}

Penilaian terhadap kebiasaan responden menggunakan obat dilakukan dengan memberi point 1 jika kebiasaan responden mengarah pada kebiasaan penggunaan obat yang baik. Poin " 0 " diberikan jika kebiasaan responden tidak mengarah pada penggunaan obat yang baik. Kebiasaan responden diklasifikasikan berdasarkan tabel 2 .

\section{Tabel 2. Klasifikasi Kebisaan Responden}

\begin{tabular}{|l|c|}
\hline \multicolumn{1}{|c|}{ Klasifikasi } & Nilai Responden \\
\hline Kebisaan positif & $>50 \%$ \\
\hline Kebiasaan negatif & $\leq 50 \%$ \\
\hline
\end{tabular}

Pengaruh tingkat pengetahuan tentang penanganan obat dalam swamedikasi terhadap kebiasan responden dalam menggunakan obat diuji menggunakan uji korelasi Spearman.

\section{HASIL DAN PEMBAHASAN}

\section{Gambaran tingkat pengetahuan responden.}

Green (1980) dalam Notoatmodjo (2010) menyatakan bahwa perilaku kesehatan dapat dipengaruhi oleh pengetahuan, sikap, kenyakinan, nilai-nilai (predisposing factor); fasilitas kesehatan, sarana kesehatan, sumber daya (enabling factor); dan tokoh masyarakat, pelayanan petugas kesehatan, teman, keluarga (reinforcing factor). Penggunaan obat bebas dan obat bebas terbatas yang sesuai dengan aturan dan kondisi penderita akan mendukung upaya penggunaan obat yang rasional (Kristina dkk, 2008)
Kuesioner tingkat pengetahuan tentang penanganan obat dalam swamedikasi memuat pertanyaan-pertanyaan mengenai penggolongan obat, reaksi efek samping, kontraindiasi, frekuensi minum obat,cara penyimpanan obat, ciri-ciri obat rusak, dan penanganan obat rusak atau kadaluwarsa

Hasil penelitian menunjukkan sebagian besar responden memiliki tingkat pengetahuan penanganan obat dalam swamedikasi yang cukup yaitu sebanyak 28 orang, 20 orang memiliki tingkat pengetahuan baik dan 2 orang memiliki tingkat pengetahuan yang kurang mengenai penanganan obat dalam swamedikasi.

Nilai tertinggi yang diperoleh responden untuk skor tingkat pengetahuan adalah 15 (94\% dari nilai maksimal), sedangkan nilai terendah yang diperoleh responden adalah 8 (50\% dari nilai maksimal)

Rata-rata nilai dari keseluruhan responden jika dihitung persentasenya terhadap nilai maksimal menunjukkan angka 74,12\%. Hal ini menunjukkan bahwa secara keseluruhan responden memiliki tingkat pengetahuan yang cukup tentang penanganan obat dalam swamedikasi.

Tabel 3. Distribusi Frekuensi Tingkat Pengetahuan Responden Tentang Penanganan obat dalam swamedikasi

\begin{tabular}{|c|c|c|c|}
\hline Klasifikasi & $\begin{array}{c}\text { Nilai } \\
\text { responden }\end{array}$ & $\begin{array}{c}\text { Jumlah } \\
\text { (orang) }\end{array}$ & $\begin{array}{c}\text { Persentase } \\
(\boldsymbol{\%})\end{array}$ \\
\hline Baik & $76-100 \%$ & 20 & $\mathbf{4 0}$ \\
\hline Cukup & $56-75 \%$ & 28 & $\mathbf{5 6}$ \\
\hline Kurang & $\leq 55 \%$ & 2 & $\mathbf{4}$ \\
\hline Jumlah & & $\mathbf{5 0}$ & $\mathbf{1 0 0}$ \\
\hline
\end{tabular}

Pertanyaan yang paling banyak tidak dijawab dengan benar oleh responden adalah penggolongan obat yang dapat digunakan dalam swamedikasi serta cara menangani obat yang sudah rusak atau kadaluwarsa. Hal ini menunjukkan bahwa pengetahuan masyarakat terutama pasien yang melakukan swamedikasi di Apotek Gunung Sari dapat ditingkatkan lagi, khususnya mengenai obat-obatan yang dapat mereka peroleh tanpa resep dokter dan cara penanganan obat yang rusak atau kadaluwarsa

\section{Gambaran kebiasaan responden menggunakan obat}

Hasil penelitian menunjukkan bahwa sebagian besar responden memiliki kebisaan menggunakan obat yang positif. Tabel 4 menunjukan bahwa 96\% dari responden memiliki kebiasaan menggunakan obat yang positif. 
Rata-rata nilai dari keseluruhan responden jika dihitung persentasenya terhadap nilai maksimal menunjukkan angka 75,17\%. Hal ini menunjukkan bahwa umumnya responden memiliki kebisaan penggunaan obat yang positif. Kebiasaan positif ini menunjukkan masyarakat cenderung mendapatkan obat dan informasi mengenai penggunaan obat tersebut dari tempat pelayanan kesehatan.

Tabel 4. Distribusi Frekuensi Kebisaan Responden Menggunakan Obat

\begin{tabular}{|l|c|c|c|}
\hline Klasifikasi & $\begin{array}{c}\text { Nilai } \\
\text { responden }\end{array}$ & $\begin{array}{c}\text { Jumlah } \\
\text { (orang) }\end{array}$ & $\begin{array}{c}\text { Persentase } \\
(\%)\end{array}$ \\
\hline $\begin{array}{l}\text { Kebiasaan } \\
\text { positif }\end{array}$ & $>50 \%$ & 48 & 96 \\
\hline $\begin{array}{l}\text { Kebiasaan } \\
\text { negatif }\end{array}$ & $\leq 50 \%$ & 2 & 4 \\
\hline Jumlah & & $\mathbf{5 0}$ & $\mathbf{1 0 0}$ \\
\hline
\end{tabular}

Hubungan tingkat pengetahuan tentang penanganan obat dalam swamedikasi terhadap kebiasan responden dalam menggunakan obat berdasarkan swamedikasi

Pengaruh tingkat pengetahuan tentang penanganan obat dalam swamedikasi terhadap kebiasan responden dalam menggunakan obat dianalisis menggunakan uji korelasi Spearman karena data skor kebiasaan responden tidak terdistribusi normal.

Tabel 5. Hasil Uji Korelasi Spearman

\begin{tabular}{|l|l|l|}
\hline \multicolumn{4}{|c|}{ Kebiasan responden dalam menggunakan obat } \\
\hline $\begin{array}{l}\text { Tingkat } \\
\text { pengetahuan } \\
\text { tentang }\end{array}$ & Koefisien korelasi (r) & $-0,036$ \\
\cline { 2 - 3 } $\begin{array}{l}\text { penanganan obat } \\
\text { dalam swamedikasi }\end{array}$ & Nilai signifikansi (p) & 0,802 \\
\cline { 2 - 3 } & Jumlah subjek (n) & 50 \\
\hline
\end{tabular}

Hasil pengujian menunjukkan nilai signifikansi $>0,05$ dengan koefisien korelasi negatif yang dapat diartikan bahwa tidak ada korelasi yang bermakna antara tingkat pengetahuan tentang penanganan obat dalam swamedikasi dan kebiasan responden dalam menggunakan obat. Diduga ada banyak faktor lain yang berpengaruh pada kebiasaan penggunaan obat, diantaranya sikap, kenyakinan, nilai-nilai (predisposing factor); fasilitas kesehatan, sarana kesehatan, sumber daya (enabling factor); dan tokoh masyarakat, pelayanan petugas kesehatan, teman, keluarga (reinforcing factor).

\section{SIMPULAN}

1. Tingkat pengetahuan responden di Apotek Gunung Sari tentang penanganan obat dalam swamedikasi termasuk dalam kategori cukup.

2. Tidak ada pengaruh tingkat pengetahuan tentang penanganan obat dalam swamedikasi terhadap kebiasan responden dalam menggunakan obat berdasarkan uji korelasi Spearman.

\section{DAFTAR PUSTAKA}

Badan Pusat Statistik, 2011. Indikator kesehatan 1995-2011. Diakses dari: http://www.bps.go.id/ pada 24 agustus 2016

FIP, 1999. Joint Statement By The International Pharmaceutical Federation and The World Self Medication Industry: Responsible SelfMedication. FIP \& WSMI, p.1-2.

Kamus Besar Bahasa Indonesia online http://kamusbahasaindonesia.org/kebiasaan

KamusBahasaIndonesia.org diakses tanggal 24 Agustus 2016

Kristia, Susi Ari, Yayi Suryo Prabandari, dan Riswaka Sudjaswadi, Perilaku pengobatan sendiri yang rasional pada masyarakat Kecamatan Depok dan Cangkringan Kabupaten Sleman, Majalah Farmasi Indonesia, 19(1), 32-40

Lemenshow,S., Hosmer Jr., D.W., Klar, J., dan Lwanga, S.K., 1997, Besar Sampel Dalam Penelitian Kesehatan, diterjemahkan oleh Dibyo Pramono, 54-55, Gadjah Mada University Press, Yogyakarta

Notoatmodjo, S., 2003. Pendidikan dan Perilaku Kesehatan. Jakarta: PT. Rineka Cipta.

2010, Ilmu Perilaku Kesehatan, Jakarta: PT. Rineka Cipta.

Pratiwi, Puji Ningrum, Liza Pristianty, Gusti Noorrizka, Anila Impian, 2014, Pengaruh Pengetahuan terhadap Perilau Swamedikasi Obat Anti Inflamasi Non-steroid Oral pada Etnis Thionghoa di Surabaya, Jurnal Farmasi Komunitas Vol 1 No 2 hal 36-40 
World Health Organization, 2012, The Pursuit of Responsible Use of Medicines:Sharing and Learning from Country Experiences, (online),(http://www.who.int/medicines/are as/rational_use/en/ diakses tanggal 17/1/2014). 